\title{
Family history of breast and ovarian cancer and triple negative subtype in hispanic/latina women
}

\author{
Kristin Anderson ${ }^{1}$, Patricia A Thompson ${ }^{2}$, Betsy C Wertheim², Lorena Martin², lan K Komenaka ${ }^{4}$, Melissa Bondy ${ }^{5}$, \\ Adrian Daneri-Navarro ${ }^{6}$, Maria Mercedes Meza-Montenegro ${ }^{7}$, Luis Enrique Gutierrez-Millan ${ }^{8}$, Abenaa Brewster ${ }^{9}$, \\ Lisa Madlensky ${ }^{1,3}$, Malaika Tobias', Loki Natarajan ${ }^{1,3}$ and María Elena Martínez ${ }^{1,3^{*}}$
}

\begin{abstract}
Familial breast and ovarian cancer prevalence was assessed among 1150 women of Mexican descent enrolled in a case-only, binational breast cancer study. Logistic regression was conducted to compare odds of triple negative breast cancer (TNBC) to non-TNBC according to family history of breast and breast or ovarian cancer among 914 of these women.

Prevalence of breast cancer family history in a first- and first- or second-degree relative was $13.1 \%$ and $24.1 \%$, respectively; that for breast or ovarian cancer in a first-degree relative was $14.9 \%$. After adjustment for age and country of residence, women with a first-degree relative with breast cancer were more likely to be diagnosed with TNBC than non-TNBC $(\mathrm{OR}=1.98 ; 95 \% \mathrm{Cl}, 1.26-3.11)$. The odds of TNBC compared to non-TNBC were $1.93(95 \% \mathrm{Cl}$, 1.26-2.97) for women with a first-degree relative with breast or ovarian cancer. There were non-significant stronger associations between family history and TNBC among women diagnosed at age $<50$ compared to $\geq 50$ years for breast cancer in a first-degree relative $(P$-interaction $=0.14)$ and a first- or second-degree relative $(P$-interaction $=0.07)$. Findings suggest that familial breast cancers are associated with triple negative subtype, possibly related to BRCA mutations in Hispanic/Latina women, which are strongly associated with TNBC. Family history is an important tool to identify Hispanic/Latina women who may be at increased risk of TNBC, and could benefit from prevention and early detection strategies.
\end{abstract}

Keywords: Triple negative breast cancer; Hispanic; Family history; Risk factor heterogeneity

\section{Background}

Having a first-degree relative with breast cancer is associated with a 2 -fold increase in risk of developing the disease, despite the fact that mutations in high-risk alleles such as BRCA1/2 explain less than $20 \%$ of familial cancers (Collaborative Group on Hormonal Factors in Breast, C 2001, Mavaddat et al. 2010). Breast cancer is a heterogeneous disease with differences in patient outcomes based on tumor hormone receptor status and expression of human epidermal growth factor receptor 2 (HER2). Gene expression studies have confirmed the existence of at least four distinct and reproducible breast

\footnotetext{
* Correspondence: e8martinez@ucsd.edu

'Moores Cancer Center, University of California San Diego, 3855 Health

Sciences Dr., \#0901, La Jolla, CA 92093-0901, USA

${ }^{3}$ Department of Family and Preventive Medicine, University of California San Diego, La Jolla, CA, USA

Full list of author information is available at the end of the article
}

cancer subtypes with molecular differences based on these markers (Perou et al. 2000). These differences have resulted in stratification in the clinical setting with varying treatment algorithms based on subtype (Paik et al. 2006, Slamon et al. 2011).

Epidemiological studies provide additional evidence supporting differential effects of reproductive risk factors on risk of developing hormone receptor positive or negative tumors, as we recently reviewed (Anderson et al. 2014), which also include case-only studies (Martinez et al. 2010). Non-reproductive risk factors, such as obesity, have also been shown in a recent meta-analysis to confer a greater risk for triple negative breast cancer (TNBC) compared to non-TNBC, particularly among pre-menopausal women (Pierobon and Frankenfeld 2013). Results of some studies, which are reviewed here (Additional file 1: Table S1), have also shown differences in risk by subtype according to family history, but results are inconsistent. These findings

\section{实}


underscore heterogeneity in etiology among breast tumors. Furthermore, genetic variation in susceptibility to breast cancer within certain racial/ethnic populations, along with interactions of these heritable risk factors with environmental and reproductive risk factors, may contribute to differences in breast cancer risk and outcomes by tumor subtype.

Relatively little data exist on risk of breast cancer associated with family history of breast and ovarian cancers in Hispanic/Latina women, and fewer reports have been published on associations by tumor subtype (Hines et al. 2008, Jiang et al. 2012). Furthermore, there is a paucity of information on the family history profile of breast and ovarian cancer in this ethnic group. Such information could help identify the degree of misreporting due to lack of awareness or limited family structure, resulting from few female family members who have survived to older ages (Weitzel et al. 2007a). Importance of improved family history ascertainment relates to the recent publication of Hispanic/Latina breast and ovarian cancer families in the U.S. that showed a high prevalence of BRCA mutations (25\%) (Weitzel et al. 2013).

To address these important gaps, here we first describe the self-reported breast and ovarian family history profile in a breast cancer case series of women of Mexican descent. We then assess odds of TNBC according to family history of breast and ovarian cancer.

\section{Methods}

\section{Study population}

The Ella Binational Breast Cancer Study is a case-only study of invasive breast cancer; details of the study have been previously described (Martínez et al. 2010). Mexican and Mexican-American women age 18 years or older were recruited within 24 months of diagnosis. Recruitment sites included two in the U.S. (the University of Arizona Cancer Center in Tucson, Arizona and the M.D. Anderson Cancer Center in Houston, Texas) and three in Mexico (the Universidad de Sonora in Hermosillo, Sonora; the Instituto Tecnológico de Sonora in Ciudad Obregón, Sonora; and the Universidad de Guadalajara in Guadalajara, Jalisco). All sites used a predominately clinic-based recruitment strategy. Recruitment occurred from March 2007 through June 2011, with response rates ranging from 95-99\% (Martínez et al. 2010). The Institutional Review Board from each participating institution approved the study protocol, and all women provided informed consent. IRB approvals: 1. UCSD Human Research Protections Program; 2. University of Arizona Human Subjects Protection Program; 3. The University of Texas MD Anderson Cancer Center Institutional Review Board; 4. Commission on Ethics, Investigation and Biosafety, University of Guadalajara; 5. Committee on Ethics, Instituto Jaliscience de Cancerologia; 6. National Commission on Scientific
Research of the Instituto Nacional del Seguro Social; 7. Bioethics Institutional Committee, Instituto Tecnologico de Sonora.

\section{Data collection and variable definition}

Risk factor data were ascertained from an interviewadministered questionnaire that included sociodemographics, reproductive history, family history of cancer, and other risk factor data. Details were previously published (Martínez et al. 2010, Martinez et al. 2013) and are further described below.

Comprehensive family history data were collected to include first-degree (brother, sister, son, daughter, father, mother) and second-degree (grandfather, grandmother, uncle, aunt) relatives. Half-siblings were not included. A total of 1150 participants were asked, "Have any of your immediate family members ever been diagnosed with cancer?" Those who answered "yes" $(n=612)$ were then asked to report the type of cancer for each family member and his/her age at diagnosis. Women who answered "no" $(n=510)$ or "don't know" $(n=28)$ did not supply any additional information regarding family history of cancer. We also asked participants whether they were adopted and, if so, whether they knew her blood relatives. A woman who reported that she was adopted and did not know her blood relatives was categorized as "don't know"; adopted women who knew their blood relatives were categorized as positive or negative for family history according to their response.

For breast or ovarian cancer family history, we counted the number of women who reported a history of these malignancies in first- or second-degree relatives. Women who reported a female relative with cancer of unknown type were classified as "unknown" for the relevant family history variables, depending on whether the relative in question was first or second degree, which contributed to differences in the denominators available for each variable.

\section{Clinical data}

Age at diagnosis and tumor marker data for estrogen receptor (ER), progesterone receptor (PR), and HER2 were abstracted from medical records. In the abstraction, priority was given to a numeric value for the percent of cells staining, where ER and PR positivity was defined as $\geq 1 \%$ cell staining by immunohistochemistry (IHC). Cases were considered HER2+ if amplified as determined by fluorescence in situ hybridization (FISH; ratio 22.2 ). If no FISH results were available, an IHC intensity score of $3 / 3+$ was considered positive, $2 / 2+$ equivocal, and $0 / 1 / 1+$ negative. If the IHC intensity score was $3 / 3+$, that tumor was classified as HER2+ regardless of FISH value. Tumors with an equivocal HER2 IHC intensity score and no FISH data were excluded $(n=53)$. Cases were categorized as either TNBC (ER-, PR-, and 
HER2-) or non-TNBC, which included luminal A (ER+ and/or PR+ and HER2-), luminal B (ER+ and/or PR+ and HER2+), and HER2+ (ER-/PR- and HER2+) cancers. Of the 1150 women who were asked about their family history, 960 had known TNBC status, of which 914 had known status for family history of breast cancer in a firstor second-degree relative.

\section{Statistical analysis}

Descriptive statistics (mean \pm SD and proportions) for family history and risk factor characteristics were calculated. Associations between family history and TNBC status were tested using logistic regression, using nonTNBC as the reference group. Since the primary objective was to quantify the associations between presence of family history of breast cancer and TNBC as a means of understanding tumor heterogeneity rather than building risk models, the models were adjusted only for age at diagnosis (continuous) and recruitment country (U.S. or Mexico). In addition, we found minimal differences in the distributions of reproductive factors by family history, suggesting a lack of confounding by these variables. Analogous models were conducted for family history of breast or ovarian cancer. Each model generated an odds ratio (OR) and 95\% confidence interval (CI). Tests for interaction between age and family history on TNBC status were conducted using likelihood ratio tests. All statistical analyses were performed using Stata 13.1 (StataCorp, College Station, TX).

\section{Results}

A family history of breast cancer in a first-degree relative was reported by $13.1 \%$ of participants, and $24.1 \%$ reported breast cancer in a first- or second-degree relative (Table 1). The prevalence of a reported history of breast or ovarian cancer in a first-degree relative was $14.9 \%$. Among women who were diagnosed at age $<50$ years, the prevalence of family history of breast cancer in a first- or second-degree relative increased to $27.4 \%$. Few women reported more than one relative with breast or ovarian cancer.

Table 2 shows age and reproductive factors of women with at least one first-degree relative with breast cancer compared with women with no affected first-degree relatives. Analysis was restricted to the 914 women who had data for tumor subtype and knowledge of their family history of breast cancer in any relative. The mean age at diagnosis was similar between the two groups, as was parity, age at first full-term pregnancy, menstrual history, and breastfeeding history. However, differences by country of residence were shown for family history, wherein women recruited from Mexico were less likely to report a family history than women from the U.S.
Table 1 Summary of family history of breast and/or ovarian cancer in the Ella study

\begin{tabular}{lr}
\hline Family history characteristic & n/total (\%) \\
\hline Family history of any cancer in first- or & \\
second-degree relative & \\
No & $510 / 1150(44.4)$ \\
Yes & $612 / 1150(53.2)$ \\
Unknown due to adoption & $9 / 1150(0.78)$ \\
(participant does not know her blood relatives) & \\
Unknown (other reason) & $19 / 1150(1.65)$ \\
Family history of breast cancer & \\
In a first-degree relative & $146 / 1112(13.1)$ \\
In a first- or second-degree relative & $264 / 1096(24.1)$ \\
In a first- or second-degree relative and & $138 / 504(27.4)$ \\
participant's age of diagnosis < 50 y & \\
Family history of breast or ovarian cancer & \\
In a first-degree relative & $166 / 1112(14.9)$ \\
In a first- or second-degree relative & $293 / 1096(26.7)$ \\
In a first- or second-degree relative and & $147 / 504(29.2)$ \\
participant's age of diagnosis < 50 y & \\
Number of first-degree relatives with breast & \\
or ovarian cancer & \\
0 & \\
\hline &
\end{tabular}

Number of first- or second-degree relatives with breast or ovarian cancer

0

803/1096 (73.3)

2

226/1096 (20.6)

45/1096 (4.11)

$3+$

22/1096 (2.01)

${ }^{*}$ No participants reported more than 3 first-degree relatives with breast or ovarian cancer.

Among women with non-TNBC, $13.5 \%$ had a family history of breast cancer in a first-degree relative, compared with $21.6 \%$ of women with TNBC (Table 3). The prevalence of a family history of breast or ovarian cancer in a first-degree relative was $15.5 \%$ among patients with non-TNBC, compared with $24.3 \%$ among women with TNBC. After adjustment for age and country of residence, the OR (95\% CI) for TNBC versus non-TNBC for women with a history of breast cancer in a first-degree relative was 1.98 (1.26-3.11), and that for women with an affected first- or second-degree relative was 2.04 (1.40-2.98). The odds of TNBC compared to non-TNBC were 1.93 (95\% CI, 1.25-2.97) for women with a firstdegree relative affected with breast or ovarian cancer.

We next conducted stratified analysis by age at diagnosis of the participant (Table 4). For all family history variables assessed, we observed a trend towards stronger 
Table 2 Risk factors in the Ella study by family history of breast cancer* $(n=914)$

\begin{tabular}{ccc}
\hline Risk factor & $\begin{array}{c}\text { First-degree } \\
\text { family history }\end{array}$ & $\begin{array}{c}\text { No first-degree } \\
\text { family history }\end{array}$ \\
$(n=135)$ & $(n=779)$ \\
$n(\%)$ & $n(\%)$ \\
\hline
\end{tabular}

Age at diagnosis, y

$$
<50
$$$$
\geq 50
$$

Mean \pm SD

Age at menarche, $y$

$$
\begin{aligned}
& <13 \\
& \geq 13 \\
& \text { Mean } \pm \text { SD }
\end{aligned}
$$

Parity

$$
\begin{aligned}
& \text { Nulliparous } \\
& 1-2 \text { children } \\
& \geq 3 \text { children } \\
& \text { Mean } \pm \text { SD }
\end{aligned}
$$

Age at first full term pregnancy, $y$

$$
<21
$$$$
21-24
$$$$
\geq 25
$$

\section{Unknown}

Nulliparous

Mean \pm SD

Time since last full-term pregnancy, $y$

$$
>10
$$$$
\leq 10
$$

Postmenopausal or unknown

Premenopausal but nulliparous

Mean \pm SD

\begin{tabular}{|c|c|c|}
\hline \multicolumn{3}{|c|}{ Breastfeeding duration per birth, mo } \\
\hline Never & $31(25.4)$ & $170(24.2)$ \\
\hline$>0-5$ & $54(44.3)$ & $269(38.2)$ \\
\hline$\geq 5$ & $37(30.3)$ & $265(37.6)$ \\
\hline Nulliparous & 13 & 75 \\
\hline Mean \pm SD & $4.5 \pm 6.6$ & $5.3 \pm 6.8$ \\
\hline \multicolumn{3}{|l|}{ Menopausal status at diagnosis } \\
\hline Pre & $64(47.8)$ & $386(50.2)$ \\
\hline Post & $70(52.2)$ & $383(49.8)$ \\
\hline Unknown & 1 & 10 \\
\hline \multicolumn{3}{|l|}{ Age at menopause, y } \\
\hline$<50$ & $41(58.6)$ & $226(59)$ \\
\hline$\geq 50$ & $29(41.4)$ & $157(41)$ \\
\hline Premenopausal at diagnosis & 64 & 386 \\
\hline Unknown & 1 & 10 \\
\hline Mean \pm SD & $46.9 \pm 6.9$ & $47.3 \pm 6.5$ \\
\hline \multicolumn{3}{|l|}{ Hormone replacement therapy } \\
\hline Never & $117(87.3)$ & $674(87.3)$ \\
\hline Ever & $17(12.7)$ & $98(12.7)$ \\
\hline Unknown & 1 & 7 \\
\hline \multicolumn{3}{|l|}{ Hormone contraceptive use } \\
\hline Never & $58(43.0)$ & $345(44.3)$ \\
\hline Ever & $77(57.0)$ & $434(55.7)$ \\
\hline \multicolumn{3}{|c|}{ Tertile of duration of menstruation, $y$} \\
\hline $7.6-27.35$ & $21(15.6)$ & $172(22.1)$ \\
\hline $27.4-33.45$ & $40(29.6)$ & $201(25.8)$ \\
\hline $33.5-50.5$ & $65(48.1)$ & $343(44)$ \\
\hline Unknown & $9(6.7)$ & $63(8.1)$ \\
\hline Mean \pm SD & $33.2 \pm 6.7$ & $32.1 \pm 7.3$ \\
\hline \multicolumn{3}{|l|}{ Country of residence } \\
\hline Mexico & $46(11.5)$ & $355(88.5)$ \\
\hline U.S. & 89 (17.3) & $424(82.7)$ \\
\hline
\end{tabular}

Time from menarche to first pregnancy, $y$

$$
\begin{aligned}
& <8 \\
& 8-12 \\
& \geq 13 \\
& \text { Unknown } \\
& \text { Nulliparous }
\end{aligned}
$$

Mean \pm SD

Lifetime duration of

breastfeeding, mo

$\begin{array}{lcc}\text { Never } & 31(25.4) & 170(24.1) \\ \text { Up to } 12 & 48(39.3) & 248(35.2) \\ \geq 12 & 43(35.2) & 286(40.6) \\ \text { Nulliparous } & 13 & 75 \\ \text { Mean } \pm \text { SD } & 15.6 \pm 26.2 & 18.6 \pm 31.5\end{array}$

Table 2 Risk factors in the Ella study by family history of breast cancer* $(n=914)$ (Continued)

*History of breast cancer in one or more first-degree relatives.

associations with TNBC for younger $(<50$ years $)$ than older ( $\geq 50$ years) women.

\section{Discussion}

Our results support heterogeneity in risk of tumor subtype by family history, with TNBC having a stronger association with a positive family history than non-TNBC in this case series of women of Mexican descent. The magnitude of the associations was similar among women with breast cancer history in first-degree relatives, firstor second-degree relatives, as well as those with history of breast or ovarian cancer. There was a non-significant 
Table 3 Odds of TNBC compared to non-TNBC according to family history of breast and/or ovarian cancer $(n=914)$

\begin{tabular}{|c|c|c|c|c|}
\hline Family history & $\begin{array}{c}\text { Non-TNBC } \\
n(\%)\end{array}$ & $\begin{array}{l}\text { TNBC } \\
n(\%)\end{array}$ & $\begin{array}{l}\text { TNBC vs. non-TNBC } \\
\text { OR }(95 \% \mathrm{Cl})^{*}\end{array}$ & $\begin{array}{c}\text { TNBC vs. non-TNBC } \\
\text { OR }(95 \% \mathrm{Cl})^{* *}\end{array}$ \\
\hline \multicolumn{5}{|c|}{ Breast cancer in first-degree relatives } \\
\hline No & $663(86.6)$ & $116(78.4)$ & 1.00 & 1.00 \\
\hline Yes & $102(13.5)$ & $32(21.6)$ & $1.78(1.14-2.77)$ & $1.98(1.26-3.11)$ \\
\hline \multicolumn{5}{|c|}{ Breast cancer in first- or second-degree relatives } \\
\hline No & $586(76.5)$ & $92(62.2)$ & 1.00 & 1.00 \\
\hline Yes & $180(23.5)$ & $56(37.8)$ & $1.98(1.37-2.87)$ & $2.04(1.40-2.98)$ \\
\hline \multicolumn{5}{|c|}{ Breast or ovarian cancer in first-degree relatives } \\
\hline No & $647(84.5)$ & $112(75.7)$ & 1.00 & 1.00 \\
\hline Yes & $119(15.5)$ & $36(24.3)$ & $1.75(1.13-2.67)$ & $1.93(1.25-2.97)$ \\
\hline
\end{tabular}

${ }^{*}$ Crude odds ratio.

**Adjusted for age at diagnosis and country of residence (U.S. or Mexico)

trend towards a stronger association between TNBC and positive family history among younger versus older women.

We conducted a review of the literature on prevalence of family history of breast cancer by breast tumor subtype and found 28 studies that have evaluated this relationship: 17 case-control (Rosato et al, 2013; Kawai et al, 2012; Bao et al, 2011; Yang et al, 2011; Dolle et al, 2009; Hines et al, 2008; Millikan et al, 2008; Yang et al, 2007; Rosenberg et al, 2006; Rusiecki et al, 2005; McCredie et al, 2003; Cotterchio et al, 2003; Britton et al, 2002; Huang et al, 2000; Yoo et al, 1997; Stanford et al, 1987; McTiernan et al, 1986), 9 cohort (Su et al, 2011; Phipps et al, 2011; Mavaddat et al, 2010; Setiawan et al, 2009; Welsh et al, 2009; Margolin et al, 2006; Colditz et al, 2004; Tutera et al, 1996; Potter et al, 1995), and 2 case- only studies (Song et al, 2013; Jiang et al, 2012) (Additional file 1: Table S1). Prevalence of family history among women with TNBC ranges from $5.3 \%$ in a Chinese casecase study (Song et al. 2013) to $22 \%$ among women with breast cancer age 40-84 years participating in the Breast Cancer Surveillance Consortium (Phipps et al. 2011) and $22.6 \%$ among younger women (age $<45$ years) with breast cancer in the Seattle-Puget Sound area participating in a case-control study (Dolle et al. 2009). Of the 28 studies, only 9 assessed risk of TNBC compared to other subtypes by presence of family history: 3 studies found evidence of a stronger risk of TNBC compared to other subtypes (Yang et al. 2007, Su et al. 2011, Yang et al. 2011); 3 studies reported an elevated risk of TNBC as well as other subtypes (Millikan et al. 2008, Dolle et al. 2009, Phipps et al.

Table 4 Odds of TNBC compared to non-TNBC according to family history of breast and/or ovarian cancer, stratified by participant's age at diagnosis

\begin{tabular}{|c|c|c|c|c|}
\hline \multirow[t]{2}{*}{ Family history } & \multicolumn{2}{|c|}{ Age of diagnosis $<50 \mathrm{y}$} & \multicolumn{2}{|c|}{ Age of diagnosis $\geq 50 y$} \\
\hline & $\begin{array}{c}\text { TNBC } \\
n / \text { total }(\%)\end{array}$ & OR $(95 \% \mathrm{Cl})^{*}$ & $\begin{array}{c}\text { TNBC } \\
n / \text { total (\%) }\end{array}$ & OR $(95 \% \mathrm{Cl})^{*}$ \\
\hline \multicolumn{5}{|c|}{ Breast cancer in first-degree relatives } \\
\hline No & $66 / 361(18.3)$ & 1.00 & $50 / 418(12.0)$ & 1.00 \\
\hline \multirow[t]{2}{*}{ Yes } & $21 / 58(36.2)$ & $2.61(1.43-4.77)$ & $11 / 77(14.3)$ & $1.38(0.68-2.83)$ \\
\hline & \multicolumn{4}{|c|}{ P-interaction $=0.14^{* *}$} \\
\hline \multicolumn{5}{|c|}{ Breast cancer in first- or second-degree relatives } \\
\hline No & 47/297 (15.8) & 1.00 & $45 / 381(11.8)$ & 1.00 \\
\hline \multirow[t]{2}{*}{ Yes } & 40/122 (32.8) & $2.67(1.63-4.37)$ & $16 / 114(14.0)$ & $1.37(0.73-2.56)$ \\
\hline & \multicolumn{4}{|c|}{$P$-interaction $=0.07^{* *}$} \\
\hline \multicolumn{5}{|c|}{ Breast or ovarian cancer in first-degree relatives } \\
\hline No & $66 / 357(18.5)$ & 1.00 & 46/402 (11.4) & 1.00 \\
\hline \multirow[t]{2}{*}{ Yes } & 21/62 (33.9) & $2.31(1.28-4.18)$ & 15/93 (16.1) & $1.61(0.85-3.06)$ \\
\hline & \multicolumn{4}{|c|}{ P-interaction $=0.36^{* *}$} \\
\hline
\end{tabular}

*Adjusted for country of residence (U.S. or Mexico).

**Interaction between age at diagnosis and family history on TNBC subtype. 
2011); 2 studies reported no significantly increased risk of TNBC (Welsh et al. 2009, Mavaddat et al. 2010); and one case-case study was descriptive and reported no significant differences for prevalence of family history by subtype (Song et al. 2013). In our review, we could not find any reports of family history and triple negative subtype in Hispanic/Latina women, making ours the first to report this association.

Compared to published reports on TNBC and family history of breast cancer, more data exist from studies that evaluated subtype based on only hormone receptor status with no information on HER2. Among the 26 case-control or cohort studies included in this literature review, 22 studies evaluated risk by hormone receptor status. Of these, 2 studies found a stronger association with ER+ versus ER- tumors (Welsh et al. 2009, Rosato et al. 2013). Four studies reported a stronger association for ER- versus ER+ tumors (Huang et al. 2000, Kawai et al. 2012), with one study finding this relationship only among Hispanic women (Hines et al. 2008) and another showing that the association held only among women with a first-degree relative diagnosed at age $<45$ years (Tutera et al. 1996). The remaining 16 studies found no statistically significant differences in risk by hormone receptor status. Finally, the single published case-case study is from a Spanish population, which showed ERor PR- cancers to be more likely than $\mathrm{ER}+$ or $\mathrm{PR}+$ to be associated with family history, but only among women age $<50$ years (Jiang et al. 2012). It is important to note that of the 28 studies included in this review, only 2 included Hispanic/Latina women (Hines et al. 2008, Jiang et al. 2012), which underscores the tremendous scarcity of published data in this ethnic group.

Our findings are consistent with those of Hines et al. (2008), who reported a higher risk of ER- tumors associated with family history of breast cancer among Hispanic women in the southwestern U.S. Interestingly, they did not observe this association among non-Hispanic whites, a finding that further supports the potential role of $B R C A$ founder mutations in Hispanics (Weitzel et al. 2007b). Weitzel et al. recently published results of a study of Hispanic/Latina women living in the southwestern U.S. who had either a personal or family history of breast and/ or ovarian cancer; deleterious $B R C A$ mutations were detected in $25 \%$ of participants (Weitzel et al. 2013). In a second report of breast cancer cases in Mexico, such mutations were detected in $28 \%$ of ovarian and $15 \%$ of breast cancer cases (Villarreal-Garza et al. 2014). These results suggest that $B R C A$ mutations may account for a higher percentage of familial breast cancer in women of Mexican descent than in other racial/ethnic groups (Weitzel et al. 2013). Given that greater than $80 \%$ of $B R C A$ mutated tumors are known to be TNBC (Penault-Llorca and Viale 2012), this provides a viable explanation for our results.
Recent studies of genetic variation and breast cancer risk in Hispanic/Latina women have found further evidence of unique genetic factors that are important in this population (Fejerman et al. 2014). These findings further support the need to incorporate both ancestry and family history in studies of breast cancer risk factors.

It is recognized that accuracy in reporting family history of cancer is variable across studies, albeit reporting of breast cancer history has been shown to be of higher quality than that for other malignancies (Eerola et al. 2000, Murff et al. 2004, Mai et al. 2011). Family history reporting has also been found to be more accurate among first-degree relatives than second-degree or more-distant relatives (Eerola et al. 2000, Ivanovich et al. 2002, Mai et al. 2011). Data are sparse on accuracy of reporting of family history in different racial/ethnic or immigrant populations. Orom et al. noted that reporting is less accurate in immigrant groups and that non-white immigrants are less likely to report a family history of cancer than their white counterparts (Orom et al. 2008). John et al. showed that foreign-born Hispanic women reported a lower frequency of family history of breast cancer than U.S.-born Hispanics, which was evident among case and control women. Furthermore, there was a clear and significant increasing trend in prevalence of family history by level of acculturation in both pre- and post-menopausal women (John et al. 2005). Our results show that women in the U.S. had modestly higher selfreported family history of breast cancer than those in Mexico (17.3\% versus $11.5 \%$ ). This difference might reflect the underlying risk of breast cancer, awareness and knowledge across sub-groups, or both.

In spite of the potential for misreporting of family history, reporting is unlikely to be influenced by tumor subtype, which gives credibility to our findings. In addition, the fact that we observed consistently stronger, though non-significant, associations between family history and TNBC among younger women compared to older women may also be indicative of the high prevalence of $B R C A$ mutation carriers in this population, who tend to be diagnosed with breast cancer at a younger age than do those with sporadic cancers (Weitzel et al. 2013). These findings underscore the importance of collecting a thorough family history in the oncology clinic and primary care setting, as it can affect approaches to prevention, treatment, and overall risk assessment (Murff et al. 2004, Orom et al. 2008, Wideroff et al. 2010, Mai et al. 2011). A recent American Society of Clinical Oncology consensus statement provides guidelines on the collection and use of cancer family history data ( $\mathrm{Lu}$ et al. 2014). According to the guidelines, a minimum adequate family history for patients with cancer should include any family history in first- or second-degree relatives, with the type and age at diagnosis of each primary cancer. The history should be 
taken at the initial visit and updated periodically, with appropriate referrals made to genetic counseling for highrisk individuals.

Improvement in collection of family history through new tools and instruments targeting English- and Spanishspeaking Hispanic/Latina women in the U.S. should be a priority for future research, especially given that this group has been shown to be willing to participate in cancer genetic services (Ricker et al. 2006) and to embrace and act upon genetic counseling and risk assessment information (Lagos et al. 2008). Identification of a strong family history can ultimately affect treatment plans, screening practices, and prevention options both for patients and their relatives, which may include genetic testing for $B R C A$ mutations.

Strengths of this study include the unique population comprising a large case series of women of Mexican descent residing in the U.S. and Mexico, as well as high participation rates, ranging between 95-99\% (Martínez et al. 2010). Though our sample size was large, it was not sufficiently powered to allow for subset analyses based on age of diagnosis for both the participant and their affected first-degree relative. We had relatively few women reporting more than one affected relative and were thus unable to conduct analyses based on number of affected relatives. A further limitation of our study is that family history was self-reported and unable to be verified, which may have led to an underestimation of family history prevalence, as noted above. Lastly, because our study employed a clinicbased recruitment strategy and was not population-based, findings may not be broadly generalizable to the Hispanic/ Latina community.

\section{Conclusions}

In summary, results of the present study suggest a strong familial cancer association with TNBC, supporting etiologic heterogeneity by tumor subtype in this population of Hispanic/Latina women. This association may be related to the prevalence of $B R C A$ founder mutations in this population, which are strongly associated with TNBC. Family history is an important tool to identify Hispanic/ Latina women who may be at increased risk of TNBC, and could benefit from prevention and early detection strategies.

\section{Additional file}

Additional file 1: Table S1. Case-control, /cohort, and case-case studies evaluating family history by breast cancer subtype.

\section{Competing interests}

The authors declare that they have no competing interests.

\section{Authors' contributions}

KA and MEM conceived of the study, created the analytical plan, and drafted the manuscript. MEM oversaw all activities. PT contributed to the design and analytical plan. LM and BW conducted the variable derivation and carried out the statistical analysis and generated preliminary results. All authors contributed by reviewing and providing revisions on drafts of the manuscript. All authors hereby contributed to the interpretation of the data and reviewed the manuscript for intellectual content, and they all approved the final version. All authors have read and approved the manuscript.

\section{Acknowledgements}

We are indebted to Julie Buckmeier, Carole Kepler, and Fang Wang for their contribution.

\section{Author details}

${ }^{1}$ Moores Cancer Center, University of California San Diego, 3855 Health Sciences Dr., \#0901, La Jolla, CA 92093-0901, USA. University of Arizona, Tucson, AZ, USA. ${ }^{3}$ Department of Family and Preventive Medicine, University of California San Diego, La Jolla, CA, USA. " Maricopa Medical Center, Phoenix, AZ, USA. ${ }^{5}$ Baylor College of Medicine, Houston, TX, USA. ${ }^{6}$ Universidad of Guadalajara, Guadalajara, México. ${ }^{7}$ Instituto Tecnológico de Sonora, Ciudad Obregón, México. ${ }^{8}$ Universidad of Sonora, Hermosillo, México. ${ }^{9}$ University of Texas M.D. Anderson Cancer Center, Houston, TX, USA.

Received: 6 November 2014 Accepted: 20 November 2014

Published: 11 December 2014

\section{References}

Anderson KN, Schwab RB, Martinez ME (2014) Reproductive risk factors and breast cancer subtypes: a review of the literature. Breast Cancer Res Treat 144(1):1-10

Bao PP, Shu XO, Gao YT, Zheng Y, Cai H, Deming SL, Ruan ZX, Su Y, Gu K, Lu W Zheng W (2011) Association of hormone-related characteristics and breast cancer risk by estrogen receptor/progesterone receptor status in the Shanghai breast cancer study. Am J Epidemiol 174(6):661-671

Britton JA, Gammon MD, Schoenberg JB, Stanford JL, Coates RJ, Swanson CA, Potischman N, Malone KE, Brogan DJ, Daling JR, Brinton LA (2002) Risk of breast cancer classified by joint estrogen receptor and progesterone receptor status among women 20-44 years of age. Am J Epidemiol 156(6):507-516

Colditz GA, Rosner BA, Chen WY, Holmes MD, Hankinson SE (2004) Risk factors for breast cancer according to estrogen and progesterone receptor status. J Natl Cancer Inst 96(3):218-228

Collaborative Group on Hormonal Factors in Breast, C (2001) Familial breast cancer: collaborative reanalysis of individual data from 52 epidemiological studies including 58,209 women with breast cancer and 101,986 women without the disease. Lancet 358(9291):1389-1399

Cotterchio M, Kreiger N, Theis B, Sloan M, Bahl S (2003) Hormonal factors and the risk of breast cancer according to estrogen- and progesterone-receptor subgroup. Cancer Epidemiol Biomarkers Prev 12(10):1053-1060

Dolle JM, Daling JR, White E, Brinton LA, Doody DR, Porter PL, Malone KE (2009) Risk factors for triple-negative breast cancer in women under the age of 45 years. Cancer Epidemiol Biomarkers Prev 18(4):1157-1166

Eerola H, Blomqvist C, Pukkala E, Pyrhonen S, Nevanlinna H (2000) Familial breast cancer in southern Finland: how prevalent are breast cancer families and can we trust the family history reported by patients? Eur J Cancer 36(9):1143-1148

Fejerman L, Ahmadiyeh N, Hu D, Huntsman S, Beckman KB, Caswell JL, Tsung K, John EM, Torres-Mejia G, Carvajal-Carmona L, Echeverry MM, Tuazon AM, Ramirez C, Consortium C, Gignoux CR, Eng C, Gonzalez-Burchard E, Henderson B, Marchand LL, Kooperberg C, Hou L, Agalliu I, Kraft P, Lindstrom S, Perez-Stable EJ, Haiman CA, Ziv E, C. Consortium (2014) Genome-wide association study of breast cancer in Latinas identifies novel protective variants on $6 q 25$. Nat Commun 5:5260

Hines LM, Risendal B, Slattery ML, Baumgartner KB, Giuliano AR, Byers T (2008) Differences in estrogen receptor subtype according to family history of breast cancer among Hispanic, but not non-Hispanic White women. Cancer Epidemiol Biomarkers Prev 17(10):2700-2706

Huang WY, Newman B, Millikan RC, Schell MJ, Hulka BS, Moorman PG (2000) Hormone-related factors and risk of breast cancer in relation to estrogen receptor and progesterone receptor status. Am J Epidemiol 151(7):703-714 
Ivanovich J, Babb S, Goodfellow P, Mutch D, Herzog T, Rader J, Whelan A (2002) Evaluation of the family history collection process and the accuracy of cancer reporting among a series of women with endometrial cancer. Clin Cancer Res 8(6):1849-1856

Jiang X, Castelao JE, Chavez-Uribe E, Fernandez Rodriguez B, Celeiro Munoz C, Redondo CM, Pena Fernandez M, Novo Dominguez A, Pereira CD, Martinez ME, Garcia-Caballero T, Fraga Rodriguez M, Antunez J, Carracedo A, Forteza-Vila J, Gago-Dominguez M (2012) Family history and breast cancer hormone receptor status in a Spanish cohort. PLoS One 7(1):e29459

John EM, Phipps Al, Davis A, Koo J (2005) Migration history, acculturation, and breast cancer risk in Hispanic women. Cancer Epidemiol Biomarkers Prev 14(12):2905-2913

Kawai M, Kakugawa Y, Nishino Y, Hamanaka Y, Ohuchi N, Minami Y (2012) Reproductive factors and breast cancer risk in relation to hormone receptor and menopausal status in Japanese women. Cancer Sci 103(10):1861-1870

Lagos VI, Perez MA, Ricker CN, Blazer KR, Santiago NM, Feldman N, Viveros L, Weitzel JN (2008) Social-cognitive aspects of underserved Latinas preparing to undergo genetic cancer risk assessment for hereditary breast and ovarian cancer. Psychooncology 17(8):774-782

Lu KH, Wood ME, Daniels M, Burke C, Ford J, Kauff ND, Kohlmann W, Lindor NM, Mulvey TM, Robinson L, Rubinstein WS, Stoffel EM, Snyder C, Syngal S, Merrill JK, Wollins DS, Hughes KS, American Society of Clinical (2014) American Society of Clinical Oncology Expert Statement: collection and use of a cancer family history for oncology providers. J Clin Oncol 32(8):833-840

Mai PL, Garceau AO, Graubard BI, Dunn M, McNeel TS, Gonsalves L, Gail MH, Greene MH, Willis GB, Wideroff $L$ (2011) Confirmation of family cancer history reported in a population-based survey. J Natl Cancer Inst 103(10):788-797

Margolin S, Johansson H, Rutqvist LE, Lindblom A, Fornander T (2006) Family history, and impact on clinical presentation and prognosis, in a populationbased breast cancer cohort from the Stockholm County. Fam Cancer 5(4):309-321

Martinez ME, Cruz Gl, Brewster AM, Bondy ML, Thompson PA (2010) What can we learn about disease etiology from case-case analyses? Lessons from breast cancer. Cancer Epidemiol Biomarkers Prev 19(11):2710-2714

Martínez ME, Gutiérrez-Millan LE, Bondy M, Daneri-Navarro A, Meza-Montenegro M, Anduro-Corona I (2010) Comparative study of breast cancer in Mexican and Mexican-American women. Health 2(9):1040-1048

Martinez ME, Wertheim BC, Natarajan L, Schwab R, Bondy M, Daneri-Navarro A, Meza-Montenegro MM, Gutierrez-Millan LE, Brewster A, Komenaka IK, Thompson PA (2013) Reproductive factors, heterogeneity, and breast tumor subtypes in women of mexican descent. Cancer Epidemiol Biomarkers Prev 22(10):1853-1861

Mavaddat N, Pharoah PD, Blows F, Driver KE, Provenzano E, Thompson D, Macinnis RJ, Shah M, Team S, Easton DF, Antoniou AC (2010) Familial relative risks for breast cancer by pathological subtype: a population-based cohort study. Breast Cancer Res 12(1):R10

McCredie MR, Dite GS, Southey MC, Venter DJ, Giles GG, Hopper JL (2003) Risk factors for breast cancer in young women by oestrogen receptor and progesterone receptor status. Br J Cancer 89(9):1661-1663

McTiernan A, Thomas DB, Johnson LK, Roseman D (1986) Risk factors for estrogen receptor-rich and estrogen receptor-poor breast cancers. J Natl Cancer Inst 77(4):849-854

Millikan RC, Newman B, Tse CK, Moorman PG, Conway K, Dressler LG, Smith LV Labbok MH, Geradts J, Bensen JT, Jackson S, Nyante S, Livasy C, Carey L, Earp HS, Perou CM (2008) Epidemiology of basal-like breast cancer. Breast Cancer Res Treat 109(1):123-139

Murff HJ, Spigel DR, Syngal S (2004) Does this patient have a family history of cancer? An evidence-based analysis of the accuracy of family cancer history. JAMA 292(12):1480-1489

Orom H, Cote ML, Gonzalez HM, Underwood W 3rd, Schwartz AG (2008) Family history of cancer: is it an accurate indicator of cancer risk in the immigrant population? Cancer 112(2):399-406

Paik S, Tang G, Shak S, Kim C, Baker J, Kim W, Cronin M, Baehner FL, Watson D, Bryant J, Costantino JP, Geyer CE Jr, Wickerham DL, Wolmark N (2006) Gene expression and benefit of chemotherapy in women with node-negative, estrogen receptor-positive breast cancer. J Clin Oncol 24(23):3726-3734

Penault-Llorca F, Viale G (2012) Pathological and molecular diagnosis of triple-negative breast cancer: a clinical perspective. Ann Oncol 23(Suppl 6):vi19-vi22

Perou CM, Sorlie T, Eisen MB, van de Rijn M, Jeffrey SS, Rees CA, Pollack JR, Ross DT, Johnsen H, Akslen LA, Fluge O, Pergamenschikov A, Williams C, Zhu SX,
Lonning PE, Borresen-Dale AL, Brown PO, Botstein D (2000) Molecular portraits of human breast tumours. Nature 406(6797):747-752

Phipps Al, Buist DS, Malone KE, Barlow WE, Porter PL, Kerlikowske K, Li Cl (2011) Family history of breast cancer in first-degree relatives and triple-negative breast cancer risk. Breast Cancer Res Treat 126(3):671-678

Pierobon M, Frankenfeld CL (2013) Obesity as a risk factor for triple-negative breast cancers: a systematic review and meta-analysis. Breast Cancer Res Treat 137(1):307-314

Potter JD, Cerhan JR, Sellers TA, McGovern PG, Drinkard C, Kushi LR, Folsom AR (1995) Progesterone and estrogen receptors and mammary neoplasia in the lowa Women's Health Study: how many kinds of breast cancer are there? Cancer Epidemiol Biomarkers Prev 4(4):319-326

Ricker C, Lagos V, Feldman N, Hiyama S, Fuentes S, Kumar V, Gonzalez K, Palomares M, Blazer K, Lowstuter K, MacDonald D, Weitzel J (2006) If we build it ... will they come?-establishing a cancer genetics services clinic for an underserved predominantly Latina cohort. J Genet Couns 15(6):505-514

Rosato V, Bosetti C, Negri E, Talamini R, Dal Maso L, Malvezzi M, Falcini F, Montella M, La Vecchia C (2013) Reproductive and hormonal factors, family history, and breast cancer according to the hormonal receptor status. Eur J Cancer Prev 23(5):412-417

Rosenberg LU, Einarsdottir K, Friman El, Wedren S, Dickman PW, Hall P, Magnusson C (2006) Risk factors for hormone receptor-defined breast cancer in postmenopausal women. Cancer Epidemiol Biomarkers Prev 15(12):2482-2488

Rusiecki JA, Holford TR, Zahm SH, Zheng T (2005) Breast cancer risk factors according to joint estrogen receptor and progesterone receptor status. Cancer Detect Prev 29(5):419-426

Setiawan WW, Monroe KR, Wilkens LR, Kolonel LN, Pike MC, Henderson BE (2009) Breast cancer risk factors defined by estrogen and progesterone receptor status: the multiethnic cohort study. Am J Epidemiol 169(10):1251-1259

Slamon D, Eiermann W, Robert N, Pienkowski T, Martin M, Press M, Mackey J, Glaspy J, Chan A, Pawlicki M, Pinter T, Valero V, Liu MC, Sauter G, von Minckwitz G, Visco F, Bee V, Buyse M, Bendahmane B, Tabah-Fisch I, Lindsay MA, Riva A, Crown J, G. Breast Cancer International Research (2011) Adjuvant trastuzumab in HER2-positive breast cancer. N Engl J Med 365(14):1273-1283

Song Q, Huang R, Li J, Fan J, Zheng S, Zhang B, Yang H, Tang Z, He J, Xie X, Li H, Li J, Qiao Y (2013) The diverse distribution of risk factors between breast cancer subtypes of ER, PR and HER2: a 10-year retrospective multi-center study in China. PLoS One 8(8):e72175

Stanford JL, Szklo M, Boring CC, Brinton LA, Diamond EA, Greenberg RS, Hoover RN (1987) A case-control study of breast cancer stratified by estrogen receptor status. Am J Epidemiol 125(2):184-194

Su Y, Zheng Y, Zheng W, Gu K, Chen Z, Li G, Cai Q, Lu W, Shu XO (2011) Distinct distribution and prognostic significance of molecular subtypes of breast cancer in Chinese women: a population-based cohort study. BMC Cancer 11:292

Tutera AM, Sellers TA, Potter JD, Drinkard CR, Wiesner GL, Folsom AR (1996) Association between family history of cancer and breast cancer defined by estrogen and progesterone receptor status. Genet Epidemiol 13(2):207-221

Villarreal-Garza C, Alvarez-Gomez RM, Perez-Plasencia C, Herrera LA, Herzog J, Castillo D, Mohar A, Castro C, Gallardo LN, Gallardo D, Santibanez M, Blazer KR, Weitzel JN (2014) Significant clinical impact of recurrent BRCA1 and BRCA2 mutations in Mexico. Cancer, doi:10.1002/cncr.29058

Weitzel JN, Lagos VI, Cullinane CA, Gambol PJ, Culver JO, Blazer KR, Palomares MR, Lowstuter KJ, MacDonald DJ (2007a) Limited family structure and BRCA gene mutation status in single cases of breast cancer. JAMA 297(23):2587-2595

Weitzel JN, Lagos VI, Herzog JS, Judkins T, Hendrickson B, Ho JS, Ricker CN, Lowstuter KJ, Blazer KR, Tomlinson G, Scholl T (2007b) Evidence for common ancestral origin of a recurring BRCA1 genomic rearrangement identified in high-risk Hispanic families. Cancer Epidemiol Biomarkers Prev 16(8):1615-1620

Weitzel JN, Clague J, Martir-Negron A, Ogaz R, Herzog J, Ricker C, Jungbluth C, Cina C, Duncan P, Unzeitig G, Saldivar JS, Beattie M, Feldman N, Sand S, Port D, Barragan DI, John EM, Neuhausen SL, Larson GP (2013) Prevalence and type of BRCA mutations in Hispanics undergoing genetic cancer risk assessment in the southwestern United States: a report from the Clinical Cancer Genetics Community Research Network. J Clin Oncol 31(2):210-216

Welsh ML, Buist DS, Aiello Bowles EJ, Anderson ML, Elmore JG, Li Cl (2009)

Population-based estimates of the relation between breast cancer risk, tumor subtype, and family history. Breast Cancer Res Treat 114(3):549-558 
Wideroff L, Garceau AO, Greene MH, Dunn M, McNeel T, Mai P, Willis G, Gonsalves L, Martin M, Graubard BI (2010) Coherence and completeness of population-based family cancer reports. Cancer Epidemiol Biomarkers Prev 19(3):799-810

Yang XR, Sherman ME, Rimm DL, Lissowska J, Brinton LA, Peplonska B, Hewitt SM, Anderson WF, Szeszenia-Dabrowska N, Bardin-Mikolajczak A, Zatonski W, Cartun R, Mandich D, Rymkiewicz G, Ligaj M, Lukaszek S, Kordek R, Garcia-Closas M (2007) Differences in risk factors for breast cancer molecular subtypes in a population-based study. Cancer Epidemiol Biomarkers Prev 16(3):439-443

Yang XR, Chang-Claude J, Goode EL, Couch FJ, Nevanlinna H, Milne RL, Gaudet M, Schmidt MK, Broeks A, Cox A, Fasching PA, Hein R, Spurdle AB, Blows F, Driver K, Flesch-Janys D, Heinz J, Sinn P, Vrieling A, Heikkinen T, Aittomaki K, Heikkila P, Blomqvist C, Lissowska J, Peplonska B, Chanock S, Figueroa J, Brinton L, Hall P, Czene K et al (2011) Associations of breast cancer risk factors with tumor subtypes: a pooled analysis from the Breast Cancer Association Consortium studies. J Natl Cancer Inst 103(3):250-263

Yoo KY, Tajima K, Miura S, Takeuchi T, Hirose K, Risch H, Dubrow R (1997) Breast cancer risk factors according to combined estrogen and progesterone receptor status: a case-control analysis. Am J Epidemiol 146(4):307-314

doi:10.1186/2193-1801-3-727

Cite this article as: Anderson et al:: Family history of breast and ovarian cancer and triple negative subtype in hispanic/latina women.

SpringerPlus 2014 3:727.

\section{Submit your manuscript to a SpringerOpen ${ }^{\circ}$ journal and benefit from:}

- Convenient online submission

- Rigorous peer review

- Immediate publication on acceptance

- Open access: articles freely available online

- High visibility within the field

- Retaining the copyright to your article

Submit your next manuscript at $\gg$ springeropen.com 